\title{
EDUKASI PENCEGAHAN PENULARAN COVID- 19 MELALUI DISIPLIN MENERAPKAN PROTOKOL KESEHATAN DI DESA PEGAYUT KABUPATEN OGAN ILIR TAHUN 2020
}

\author{
Heni Sumastri' ${ }^{1)}$, Sari Wahyuni ${ }^{1)}$ \\ ${ }^{1)}$ Politeknik Kesehatan Kementerian Kesehatan Palembang, Palembang, Sumatra Selatan, Indonesia \\ Corresponding author : Sari Wahyuni \\ E-mail : sariwahyuni@poltekkespalembang.ac.id
}

Diterima 15 November 2021, Direvisi 01 Desember 2021, Disetujui 01 Desember 2021

\begin{abstract}
ABSTRAK
Virus Corona merupakan bagian dari keluarga virus yang menyebabkan penyakit mulai dari flu hingga penyakit yang lebih berat. World Health Organization (WHO) memberi nama virus ini Severe Acute Respiratory Syndrome Coronavirus-2 (SARS-CoV-2) dan nama penyakitnya sebagai Corona Virus Disease 2019 (COVID-19). Infeksi SARS-CoV-2 pada manusia menimbulkan gejala gangguan pernapasan akut. Bukti saat ini mengindikasikan bahwa transmisi SARS-CoV-2 terjadi terutama dari orang ke orang melalui kontak langsung, tidak langsung, atau erat dengan orang yang terinfeksi melalui sekresi terinfeksi. Rekomendasi standar untuk mencegah penyebaran infeksi adalah melalui cuci tangan secara teratur, menerapkan etika batuk dan bersin, menghindari kontak secara langsung. Selain rekomendasi diatas, pemerintah juga mengajurkan untuk dapat menerapkan Slogan 4M untuk memutus mata rantai penyebaran COVID-19 yakni dengan Memakai Masker, Mencuci Tangan, Menjaga Jarak, Menghindari Kerumunan. Berdasarkan hasil observasi didapatkan bahwa pengetahuan masyarakat mengenai cara mencegah penyebaran COVID-19 masih rendah serta kurang disiplinnya masyarakat dalam menerapkan protokol kesehatan. Tujuan dari pengabdian masyarakat ini untuk meningkatkan pengetahuan dan keterampilan mengenai cara pencegahan penularan COVID-19 melalui penerapan protokol kesehatan 4M. Kegiatan dilakukan di Desa Pegayut Kabupaten Ogan Ilir pada Desember 2020 yang diikuti oleh 35 orang. Kegiatan diawali dengan persiapan, pembagian leaflet, penjelasan materi dengan metode ceramah tanya jawab, demonstrasi dan evaluasi. Hasil dalam pengabdian masyarakat ini terdapat peningkatan pengetahuan masyarakat desa mengenai cara pencegahan penularan COVID-19 melalui penerapan protokol kesehatan 4M. Luaran yang dicapai adalah peningkatan pengetahuan masyarakat mengenai cara pencegahan penularan COVID-19 dan keterampilan memakai masker dan mencuci tangan dengan benar.
\end{abstract}

Kata Kunci : covid-19; pencegahan; penularan; protokol kesehatan.

\begin{abstract}
Coronaviruses are part of a family of viruses that cause illnesses ranging from the flu to more severe diseases. The World Health Organization (WHO) named this virus Severe Acute Respiratory Syndrome Coronavirus-2 (SARS-CoV-2) and the name of the disease Corona Virus Disease 2019 (COVID-19). SARS-CoV-2 infection in humans causes symptoms of acute respiratory distress. Current evidence indicates that SARS-CoV-2 transmission occurs primarily from person to person through direct, indirect, or close contact with an infected person through infected secretions. Standard recommendations to prevent the spread of infection are through regular hand washing, practicing coughing and sneezing etiquette, avoiding direct contact. In addition to the suggestions above, the government also recommends implementing the $4 \mathrm{M}$ Slogan to break the chain of the spread of COVID-19, namely by wearing masks, washing hands, maintaining distance, and avoiding crowds. Based on the results of observations, it was found that public knowledge about how to prevent the spread of COVID-19 is still low and the community lacks discipline in implementing health protocols. This community service aims to increase knowledge and skills regarding how to prevent the transmission of COVID-19 through the application of the $4 \mathrm{M}$ health protocol. The activity was carried out in Pegayut Village, Ogan Ilir Regency, in December 2020, which was attended by 35 people. The training begins with preparation, distribution of leaflets, explanation of the material using the question and answers lecture method, demonstration, and evaluation. The results in this community service were an increase in the knowledge of the village community about how to prevent the transmission of COVID-19 through the application of the $4 \mathrm{M}$ health protocol. The output achieved was an increase in
\end{abstract}


public knowledge about how to avoid the transmission of COVID-19 and skills to wear masks and wash hands properly.

Keywords: covid-19: prevention; transmission; health protocol.

\section{PENDAHULUAN}

Virus Corona pertama kali ditemukan pada akhir Desember tahun 2019 di Kota Wuhan Provinsi Hubei China. Masyarakat dunia dibuat khawatir termasuk negara Indonesia karena munculnya wabah virus ini (Hui, D. S., I Azhar, E., Madani, T. A., Ntoumi, F., Kock, R., Dar, O., Ippolito, G., Mchugh, T. D., Memish, Z. A., Drosten, C., Zumla, A., \& Petersen, 2020). Virus Corona merupakan bagian dari keluarga virus yang menyebabkan penyakit mulai dari flu hingga penyakit yang lebih berat seperti Middle East Respiratory Syndrome (MERS-CoV) dan Severe Acute Respiratory Syndrome (SARSCoV). World Health Organization (WHO) memberi nama virus ini Severe Acute Respiratory Syndrome Coronavirus-2 (SARS-CoV-2) dan nama penyakitnya sebagai Corona Virus Disease 2019 (COVID-19) (WHO, 2019; Shi, Q., Dorling, D., Cao, G., \& Liu, 2020).

Infeksi SARS-CoV-2 pada manusia menimbulkan gejala gangguan pernapasan akut seperti demam, batuk, dan sesak napas. Pada kasus yang berat, penyakit ini dapat menyebabkan pneumonia, sindrom pernapasan akut, gagal ginjal, dan bahkan kematian. Gejala penyakit ini dapat muncul dalam 2-14 hari setelah terpapar virus tersebut (Kemenkes, 2020).

Bukti saat ini mengindikasikan bahwa transmisi SARS-CoV-2 terjadi terutama dari orang ke orang melalui kontak langsung, tidak langsung, atau erat dengan orang yang terinfeksi melalui sekresi terinfeksi seperti air liur dan sekresi saluran pernapasan, atau melalui droplet saluran napas, yang dikeluarkan saat seseorang yang terinfeksi batuk, bersin, berbicara, atau menyanyi. Droplet saluran napas dari orang yang terinfeksi juga dapat jatuh ke benda-benda, sehingga menciptakan fomit (permukaan yang terkontaminasi). Karena kontaminasi lingkungan telah didokumentasikan dalam berbagai laporan, kemungkinan orang juga dapat terinfeksi dengan cara menyentuh permukaan-permukaan ini kemudian menyentuh mata, hidung, atau mulut sebelum membersihkan tangan (WHO, 2020).

Rekomendasi standar untuk mencegah penyebaran infeksi adalah melalui cuci tangan secara teratur, menerapkan etika batuk dan bersin, menghindari kontak secara langsung dengan ternak dan hewan liar serta menghindari kontak dekat dengan siapa pun yang menunjukkan gejala penyakit pernapasan seperti batuk dan bersin. Selain itu, menerapkan Pencegahan dan Pengendalian Infeksi (PPI) saat berada di fasilitas kesehatan terutama unit gawat darurat (Kemenkes, 2020).

Selain rekomendasi diatas, pemerintah juga mengajurkan untuk dapat menerapkan Slogan 4M untuk memutus mata rantai penyebaran COVID-19 yakni dengan Memakai Masker, Mencuci Tangan, Menjaga Jarak, Menghindari Kerumunan. Hal tersebut dilakukan guna pencegahan dan pengendalian Corona Virus Disease (COVID19). Slogan tersebut dinilai sangat tepat untuk memperingatkan sekaligus salah satu bentuk sosialisasi mengajak masyarakat agar taat dan disiplin menjalankan protokol kesehatan. Pandemi COVID-19 belum tahu kapan akan berakhir sehingga dibutuhkan sinergitas yang kuat untuk bersama-sama mencegah dan memutus rantai penyebarannya.

Dalam menjaga kesehatan seseorang, terdapat dua faktor yang mempengaruhi kesehatan yakni factor perilaku dan non perilaku. Menurut B. Bloom, terdapat tiga domain/ranah dari perilaku, yaitu pengetahuan (knowledge), sikap (attitude), dan tindakan (practice). Sedangkan perilaku kesehatan tersebut, menurut L. Green, dipengaruhi dan ditentukan oleh tiga faktor yaitu faktor predisposisi, factor kemungkinan, faktor pendorong (S, 2014). Jika dilihat dari faktor predisposisi, masyarakat memiliki faktor sosiodemografi seperti perbedaan umur, jenis kelamin, pendidikan, pekerjaan serta daerah asal. Gambaran karakteristik sosiodemografi tersebut dapat mempengaruhi perilaku masyarakat serta putcome dari kesehatam masyarakat (Widayati, A., Suryawati, S., de Crespigny, C., \& Hiller, 2012).

Berdasarkan data yang diperoleh dari Puskesmas Pegayut Kabupaten Ogan Ilir Provinsi Sumatera Selatan Tahun 2020, terdapat 17 orang dengan hasil reaktif dari pemeriksaan rapid test dimana 1 orang berasal dari desa Pegayut. Selain itu jumlah terkonfirmasi COVID-19 di wilayah kerja Puskesmas Pegayut mencapai 13 Kasus, yaitu 11 kasus terdapat di desa lbul Besar 2 dan 2 kasus terdapat di desa lbul Besar 3. 
Lalu berdasarkan hasil observasi pendahuluan didapatkan beberapa permasalahan antara lain adalah rendahnya pengetahuan masyarakat mengenai covid-19 dan bagaimana mencegah penyebaran COVID-19 serta kurang disiplinnya masyarakat dalam menerapkan protokol kesehatan untuk memutus mata rantai penyebaran COVID-19. Berdasarkan permasalahan tersebut, perlu dilaksanakan kegiatan pengabdian kepada masyarakat di Desa Pegayut Kabupaten Ogan Ilir Tahun 2020 dengan tema "edukasi pencegahan penularan covid-19 melalui disiplin menerapkan protokol kesehatan".

\section{METODE}

Kegiatan dalam pengabdian masyarakat ini menggunakan metode pemberian edukasi secara penyuluhan dengan ceramah tanya jawab dan praktik serta diskusi. Kegiatan ini dilakukan untuk memberikan pemahaman kepada masyarakat desa mengenai pencegahan covid-19 melalui 4M untuk memutus mata rantai penyebaran COVID-19 yakni dengan memakai masker, mencuci tangan, menjaga jarak, menghindari kerumunan. Kegiatan pengabdian kepada masyarakat dosen Jurusan Kebidanan Poltekkes Kemenkes Palembang ini dilaksanakan di Desa Pegayut Kabupaten Ogan Ilir Provinsi Sumatera Selatan pada bulan Desember Tahun 2020.

Adapun prosedur dan alat evaluasi yang dilakukan meliputi tahap persiapan, pelaksanaan dan evaluasi. Tahap persiapan dilakukan sebelum kegiatan pengabdian masyarakat dimulai di Desa Pegayut Kabupaten Ogan Ilir Provinsi Sumatera Selatan, kemudian dilanjutkan dengan tahap pelaksanaan yakni dengan memberikan penjelasan materi yang ada pada leaflet dan standing banner mengenai bagaimana pencegahan penularan COVID-19 kepada masyarakat yang ada di Desa Pegayut Kabupaten Ogan Ilir Provinsi Sumatera Selatan. Materi yang dijelaskan diantaranya mengenai apa itu covid-19, bagaimana cara memutus rantai COVID-19 dengan melaksanakan protokol kesehatan melalui 4M yakni memakai masker, mencuci Tangan, menjaga Jarak dan menghindari Kerumunan. Kemudian selain penjelasan materi, pelaksana juga mengajarkan bagaimana cara memakai masker dan mencuci tangan dengan langkah yang benar. Pada tahap akhir dilakukan evaluasi yakni dengan melakukan post test terhadap edukasi yang telah diberikan dengan cara memberikan pertanyaan kepada masyarakat dan mempraktekkan kembali apa yang telah dijelaskan oleh pelaksana pengabdian masyarakat.

Luaran dalam kegiatan ini adalah peningkatan pengetahuan masyarakat desa tentang pencegahan penularan COVID-19 melalui 4M serta peningkatan keterampilan masyarakat dalam memakai masker dan mencuci tangan dengan benar.

\section{HASIL DAN PEMBAHASAN}

Kegiatan pengabdian masyarakat ini diawali dengan melakukan studi pendahuluan pada beberapa Desa yang ada di Kabupaten Ogan Ilir Provinsi Sumatera Selatan yang wilayahnya memiliki masyarakat terkonfirmasi COVID-19. Desa Pegayut merupakan salah satu Desa yang ada di Kabupaten Ogan Ilir Provinsi Sumatera Selatan yang wilayahnya terdapat masyarakat terkonfirmasi COVID-19. Setelah tim menentukan tempat yang akan menjadi tempat kegiatan pengabdian masyarakat, lalu tim mengajukan surat permohonan ijin pelaksanaan pengabdian masyarakat kepada Direktur Poltekkes Kemenkes lalu ke Dinas Kesehatan Kabupaten Ogan Ilir, Puskesmas Pegayut dan Kepala Desa Pegayut Kabupaten Ogan Ilir Privinsi Sumatera Selatan. Setelah mendapatkan izin kemudian pelaksana pengabdian menghubungi Kepala Desa Pegayut dan pihak Puskesmas Pegayut untuk kegiatan pengabdian masyarakat. Kemudian melakukan pengaturan jadwal pelaksanaan kegiatan pengabdian kepada masyarakat dan mempersiapkan instrumen pengabdian masyarakat berupa leaflet dan standing banner tentang protokol kesehatan dengan $4 \mathrm{M}$.

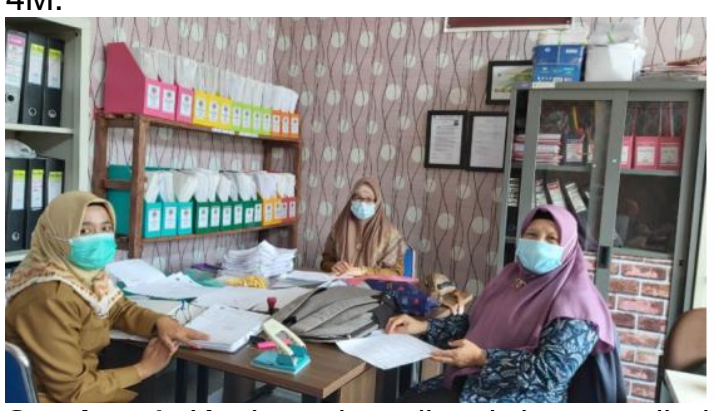

Gambar 1. Kegiatan koordinasi dengan pihak Puskesmas Pegayut

Edukasi penularan COVID-19 ini dilakukan di Balai Desa Pegayut pada bulan Desember 2020 disambut baik oleh masyarakat desa Pegayut. Banyak masyarakat desa yang memiliki rasa ingin tahu akan pengetahuan baru yang akan disampaikan oleh pelaksana pengabdi sehingga para masyarakat siap menerima edukasi mengenai penularan COVID-19. 
Berdasarkan hasil pengamatan yang dilakukan pada Desa ini terlihat masih banyak masyarakat yang lalai dalam menerapkan protokol kesehatan.

Kegiatan edukasi yang dilaksanakan ini mendapatkan respon yang positif baik dari Kepala Puskesmas Pegayut, Kepala Desa Pegayut serta tim satgas COVID-19 yang ada pada Desa Pegayut. Hal ini dikarenakan masih belum banyaknya kegiatan sejenis yang dilakukan oleh internal masyarakat Desa Pegayut pada masa pandemik COVID-19 ini. Jumlah peserta dalam kegiatan pengabdian masyarakat ini adalah 35 orang masyarakat dan tim pelaksana terdiri dari 2 orang dosen Jurusan Kebidanan Politeknik Kesehatan Kemenkes Palembang. Pada awal edukasi dimulai, setiap peserta diberikan leaflet serta pelaksana memasang standing banner yang berisikan materi penyuluhan pada ruang balai pertemuan desa pegayut. Kemudian menyampaikan materi dengan metode ceramah dan tanya jawab kepada semua peserta dan tim pelaksana menjelaskan materi yang ada pada leaflet dan standing banner tersebut.

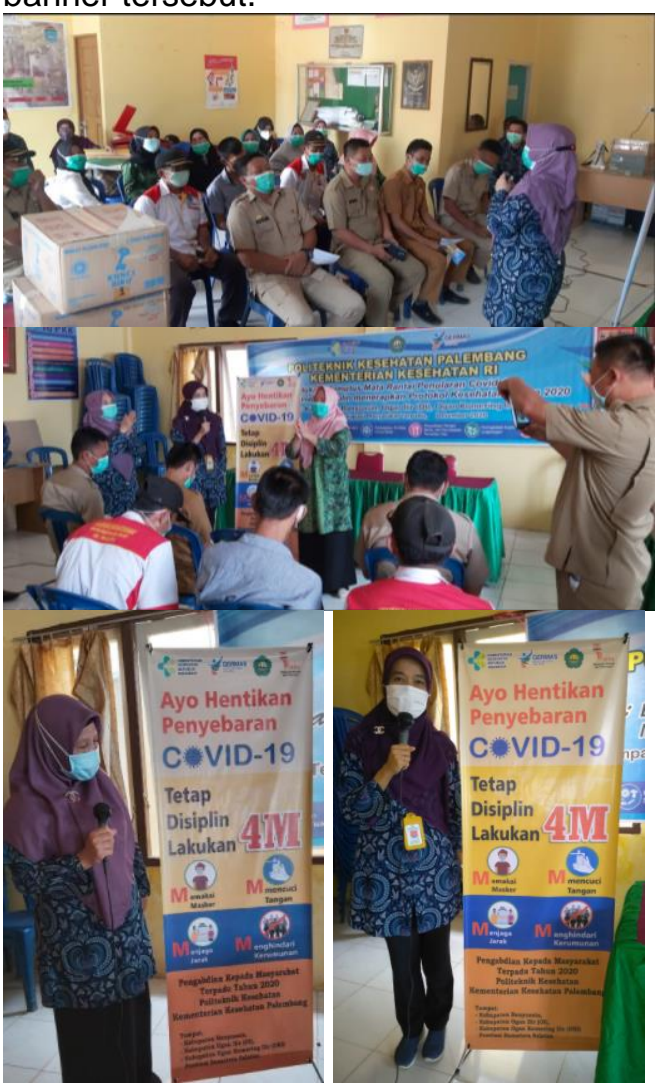

Gambar 2. Pemberian Materi Penyuluhan

Setelah materi dijelaskan tim pelaksana mendemonstrasikan atau melakukan pelatihan singkat bagaimana cara memakai masker dan mencuci tangan dengan langkah yang benar lalu setiap peserta didampingi oleh tim pelaksana, mempraktikan cara memakai masker dan mencuci tangan secara mandiri sesuai yang telah dipraktikkan oleh tim pelaksana.

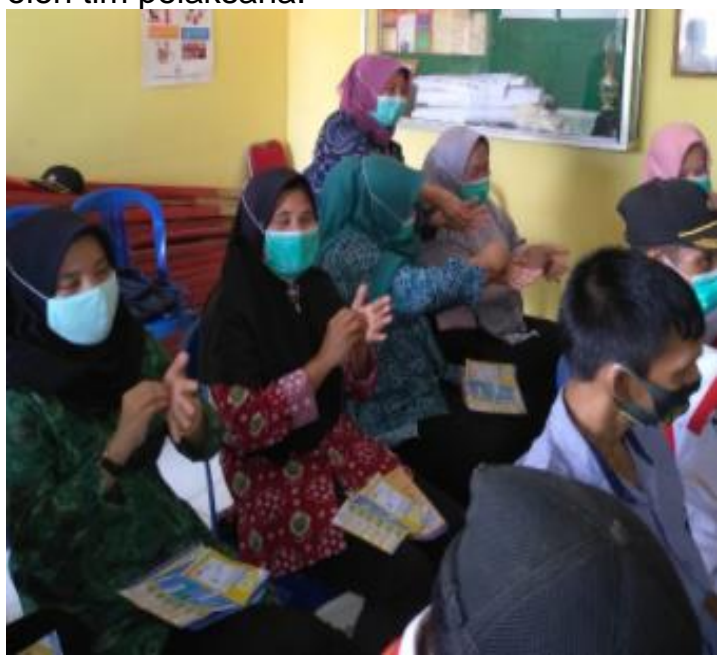

Gambar 3. Demonstrasi mencuci tangan

Sebagai bentuk evaluasi dari edukasi yang telah dilaksanakan maka dilakukan Tanya jawab terhadap peserta pengabdian masyarakat. Pemberian evaluasi tentang pencegahan COVID-19 untuk mengetahui tingkat pengetahuan dan keterampilan masyarakat desa pegayut setelah diberikan materi $4 \mathrm{M}$ serta didemostrasikan tentang cara memakai masker dan mencuci tangan. Hasil yang didapatkan setelah dilakukan evaluasi, pengetahuan dan keterampilan masyarakat Desa Pegayut mengenai pencegahan penularan COVID-19 meningkat. Hal ini terlihat dari hasil Tanya jawab yang dilaksanakan pada saat sesi diskusi dan Tanya jawab, sebagian besar masyarakat Desa Pegayut dapat menjawab pertanyaan seputar 4M yang diajukan oleh pelaksana. Masyarakat desa mengetahui bagaimana cara mencegah penularan COVID-19 melalui 4M dan masyarakat Desa Pegayut dapat mempraktekkan kembali langkah mencuci tangan dengan benar dan memakai masker dengan benar.

Hal ini sejalan dengan penelitian yang dilakukan Sari tahun 2020 bahwa terdapat hubungan antara pengetahuan masyarakat dengan kepatuhan menggunakan masker sebagai upaya pencegahan penyakit Covid-19 (Sari, D. P., \& Sholihah'Atiqoh, 2020). Begitupun dengan penelitian yang dilakukan oleh Zhong (2020), Mayoritas masyarakat China melakukan usaha seperti menggunakan masker ketika pergi keluar $(98 \%)$, dan tidak mengunjungi keramaian $(96,4 \%)$. Zhong menemukan bahwa pada masyarakat China terdapat hubungan pengetahuan dengan sikap terhadap COVID-19 (OR: $0,75, p<0.001$ ), dengan pengetahuan yang 
lebih baik menjadi faktor protektif terhadap sikap tidak percaya diri dalam menghadapi COVID-19.(Zhong, B.L., Luo, W., Li H.M., Zhang, Q.Q., Liu, X.G., Li, 2020)

Menurut ilmu psikologi sosial, sikap sangat berkaitan erat dengan tingkat pengetahuan seseorang. Sikap seseorang terhadap suatu objek menunjukkan pengetahuan orang tersebut terhadap objek yang bersangkutan. Berdasarkan teori adaptasi, tingkat pengetahuan baik dapat mendorong seseorang untuk mempunyai sikap dan perilaku yang baik pula (Silalahi, C., Lampus, B., Akili, R., Sam, U., Manado, 2013).

Menurut penelitian Moudy, dari 1096 responden yang diteliti, hampir seluruh masyarakat memiliki sikap positif mengenai COVID-19 yaitu berhati-hati dan memiliki tindakan usaha peningkatan kesehatan pribadi. Hasil tabulasi silang menunjukkan pengetahuan berpengaruh terhadap sikap dan tindakan individu sebagai usaha pencegahan COVID-19. Pemberian pengetahuan yang spesifik, valid, dan tepat sasaran dapat meningkatkan perilaku usaha pencegahan masyarakat terhadap infeksi COVID-19 (Syakurah, R. A., \& Moudy, 2020).

Diakhir pelaksanaan pengabdian masyakarat, pelaksana juga membagikan masker kepada masyarakat serta memberikan standing banner dan dipasang di Ruang Balai Pertemuan Desa Pegayut sebagai pengingat bagi para masyarakat untuk melaksanakan protokol kesehatan. Berdasarkan penelitian yang telah dilakukan oleh Adawiyah tahun 2020 didapatkan hasil bahwa analisis peran media dalam upaya pencegahan penyebaran virus corona (covid19) di Indonesia diperoleh hasil dari total 563 partisipan, sebanyak 397 partisipan berada pada kategori tinggi dengan presentasi $70,5 \%$, sebanyak 166 partisipan berada pada kategori sedang dengan presentasi $29,4 \%$, dan tidak terdapat partisipan yang berada pada kategori rendah. Hasil presentasi tersebut menunjukkan bahwa media sangat berperan dalam penerapan physical distancing dilihat dari kategori yang berada pada kategori tinggi (Adawiyah, D. P. R., \& Kadir, 2020).

Permasalahan yang sering dihadapi selama masa pandemi COVID-19 di Desa Pegayut ini adalah kurangnya penerapan protokol kesehatan secara mandiri pada masyarakat Desa Pegayut. Dengan dilaksanakannya kegiatan pengabdian kepada masyarakat pada masyarakat Desa Pegayut Kabupaten Ogan Ilir Provinsi Sumatera Selatan tentang pencegahan penularan COVID-19 diharapkan setelah selesai kegiatan edukasi ini Masyarakat Desa Pegayut mampu meningkatkan pengetahuan masyarakat tentang bagaimana cara mencegah penularan Covid-19 melalui 4M dalam menghadapi masa adaptasi baru sehingga masyarakat Desa Pegayut dapat membantu memutus mata rantai COVID-19 khususnya di Desa Pegayut Kabupaten Ogan llir Provinsi Sumatera Selatan.

\section{SIMPULAN}

Dari hasil kegiatan pengabdian masyarakat ini didapatkan hasil pengetahuan masyarakat desa Pegayut dapat meningkat, masyarakat dapat menjelaskan kembali mengenai cara pencegahan penularan COVID19 melalui 4M dan mampu mempraktekkan cara memakai masker dan mencuci tangan dengan benar. Diharapkan setelah kegiatan pengadian ini, edukasi yang telah disampaikan dapat diimplementasikan oleh masyarakat Desa Pegayut sebagai salah satu bentuk dalam memutus mata rantai COVID-19.

\section{UCAPAN TERIMA KASIH}

Terima kasih kepada Politeknik Kesehatan Kemenkes Palembang yang telah memberi dukungan dalam kegiatan pengabdian kepada masyarakat ini sehingga kegiatan pengabdian ini dapat berjalan lancer serta terima kasih kepada Kepala Desa Pegayut dan Kepala Puskesmas Desa Pegayut yang telah memberikan izin untuk dapat melaksanakan kegiatan pengabdian ini di Desa Pegayut serta tentunya kepada masyarakat Desa Pegayut Kabupaten Ogan Ilir Provinsi Sumatera Selatan. yang telah membantu dan berpartisipasi dalam kegiatan ini.

\section{DAFTAR RUJUKAN}

Adawiyah, D. P. R., \& Kadir, N. (2020). Analisis Peran Media dalam Upaya Pencegahan Penyebaran Virus Corona (Covid-19) di Indonesia. Jurnal Mediakita: Jurnal Komunikasi Dan Penyiaran Islam, 4(1).

Hui, D. S., I Azhar, E., Madani, T. A., Ntoumi, F., Kock, R., Dar, O., Ippolito, G., Mchugh, T. D., Memish, Z. A., Drosten, C., Zumla, A., \& Petersen, E. (2020). The continuing 2019- nCoV epidemic threat of novel coronaviruses to global health - The latest 2019 novel coronavirus outbreak in Wuhan, China. International Journal of Infectious Diseases, 91(3), 264-266. https://doi.org/10.1016/j.ijid.2020.01.009

Kemenkes. (2020). Pedoman Kesiapsiagaan Menghadapi Coronavirus Disease (COVID-19) Revisi ke-3. Direktorat 
Jenderal Pencegahan dan Pengendalian Penyakit.

S, N. (2014). IImu Perilaku Kesehatan. 2nd ed. Rineka Cipta.

Sari, D. P., \& Sholihah'Atiqoh, N. (2020). Hubungan antara pengetahuan masyarakat dengan kepatuhan penggunaan masker sebagai upaya pencegahan penyakit Covid-19 di Ngronggah. Infokes: Jurnal IImiah Rekam Medis Dan Informatika Kesehatan, 10(1), 52-55.

Shi, Q., Dorling, D., Cao, G., \& Liu, T. (2020). Changes in population movement make COVID-19 spread differently from SARS. Social Science \& Medicine, 255. https://doi.org/10.1016/j.socscimed.2020. 113036

Silalahi, C., Lampus, B., Akili, R., Sam, U., Manado, R. (2013). Hubungan antara pengetahuan dan sikap perawat tentang HIV / AIDS dengan tindakan perawat terhadap penderita HIV / AIDS di Rumah Sakit Pancaran Kasih Manado. Media Kesehatan FKM UNSRAT, 46, 1-5.

Syakurah, R. A., \& Moudy, J. (2020). Pengetahuan terkait usaha pencegahan Coronavirus Disease (COVID-19) di Indonesia. HIGEIA (Journal of Public Health Research and Development), 4(3), 333-346.

WHO. (2019). No Title. https://www.who.int/healthtopics/coronavi rus

WHO. (2020). Modes of transmission of virus causing COVID-19: implications for infection prevention and control (IPC) precaution recommendations.

Widayati, A., Suryawati, S., de Crespigny, C., \& Hiller, J. E. (2012). Knowledge and beliefs about antibiotics among people in Yogyakarta City Indonesia: a cross sectional population- based survey. Antimicrobial Resistance and Infection Control, 1(1), 38.

Zhong, B.L., Luo, W., Li H.M., Zhang, Q.Q., Liu, X.G., Li, W. . (2020). Knowledge, attitudes, and practices towards COVID19 among Chinese residents during the rapid rise period of the COVID-19 outbreak: a quick online cross-sectional survey. Int J Biol Sci, 16(10), 1745-1752. 